\title{
Valorization of Some Untreated Low Cost Adsorbents for Water Pollution Control
}

\author{
BASHKIM THAÇI ${ }^{1}$, MAJLINDA DACI-AJVAZI ${ }^{1 *}$, NEXHAT DACl ${ }^{2}$ and SALIH GASHI ${ }^{2}$ \\ ${ }^{1}$ Chemistry Department, University of Prishtina, Republic of Kosovo, \\ ${ }^{2}$ Academy of Sciences and Arts of Kosovo, Republic of Kosovo \\ *Corresponding author E-mail: majlinda.ajvazi@uni-pr.edu \\ http://dx.doi.org/10.12944/CWE.11.3.06
}

(Received: November 29, 2016; Accepted: December 21, 2016)

\begin{abstract}
The present article describes the adsorption behavior of some low cost adsorbents such as olive waste, maize cobs, bentonitic clay, wheat bran, coal ash and coffee waste, with respect to $\mathrm{Pb}^{2+}, \mathrm{Cu}^{2+}$ and $\mathrm{Zn}^{2+}$ ions. The batch method was used and parameters such as electrical conductivity, $\mathrm{pH}$, contact time, adsorbent dosage and initial and final concentration of metal ions were studied. All used adsorbents were effective, but coal ash was most effective, with total removal for all ions of over $90 \%$, with highest percentage removal from $99.2 \%$ for $\mathrm{Zn}^{2+}$ ions and $97.5 \%$ of $\mathrm{Pb}^{2+}$. Maize cob was an effective adsorbent with maximal percentage removal of $92.6 \%$ for $\mathrm{Zn}^{2+}$ ions, wheat bran had highest removal of $93.7 \%$ for $\mathrm{Pb}^{2+}$ ions as did olive waste, $97 \%$ for $\mathrm{Pb}^{2+}$ ions. Coffe waste offers considerable promise as a low-cost natural adsorbent with highest efficiency in removal of $\mathrm{Pb}^{2+}$ with $97.5 \%$ while bentonitic clay having a structure with net negative charge, which is neutralized by positively charged species, resulted also as an effective low cost adsorbent with max total removal from $92.7 \%$ for $\mathrm{Pb}^{2+}$ to $80.9 \%$ for $\mathrm{Zn}^{2+}$ ions.
\end{abstract}

Keywords: olive waste; maize cobs; bentonitic clay; wheat bran; coal ash; coffee waste;

\section{INTRODUCTION}

Through history, quality and quantity of water that was at human disposal, was a decisive factor for determining their welfare. At one time, clean fresh water supplies were considered inexhaustible. Only recently have we begun to understand that we will probably exhaust our usable water supplies and this can be directly attributed to human abuse in the form of pollution. Industrial activity alters the natural flow of materials and introduces novel chemicals into the environment which effluents contain toxic substances especially heavy metals, dyes, phenols, etc., ${ }^{1}$. Some heavy metals are necessary in small amounts for normal development of biological cycles, however most of these heavy metals are becoming toxic at high concentration ${ }^{2}$. Polluted water is aesthetically objectionable for drinking, irrigation, industrial activities and other purposes ${ }^{3}$ as pollutants alter physical, chemical and biological properties of water, hence affect human health and ultimately ecosystem. Different methods (adsorption, electrolytic or liquid extraction, electro dialysis, chemical precipitation, membrane filtration) have been developed for decontamination of industrial waters $4,5,6,7,8$. From all methods used, adsorption has been found to be superior to other techniques for purification of water in flexibility and simplicity of design, ease of operation and insensitivity to toxic pollutants ${ }^{9}, 10,11,12,13$. When comparing the adsorption materials, one must have in mind cost as a very important parameter. However, an adsorbent can be assumed as low cost if it requires little processing, is abundant in nature, or is a byproduct or waste material from another industry. Some biosorbents can bind and collect a wide range of heavy metals 
with no specific priority, whereas others are specific for certain types of metals ${ }^{14}$. Different low cost adsorbents have been used for wastewater treatment, some more effective than others ${ }^{15}, 16,17$. Activated carbon is usually derived from natural materials (biomass, lignite or coal) and has been a popular choice as an adsorbent for long time ${ }^{18,}$ ${ }^{19}$, but its high cost poses an economical problem. Different authors tried different low cost adsorbents like clays ${ }^{20}$, microbial and plant derived biomass ${ }^{21}$, chitin and zeolites ${ }^{22}$, sawdust ${ }^{23}$, rice husk ${ }^{24}$, soybean hulls ${ }^{25}$, sugarcane bagasse ${ }^{26}$, etc.

In the last decade, olive oil production has increased by approximately $40 \%$ worldwide and this implies a proportional increase in huge quantities of liquid and solid wastes. Double-fold advantage, with respect to environmental pollution, is to use such solid wastes and to convert them in inexpensive adsorbent for water pollution control. This way a part of solid waste material could be reduced, and the developed low-cost adsorbents can treat industrial wastewaters at a reasonable cost $27,28,29$. Solid residues from corn production such as corn cobs can also be used as raw materials in the production of adsorbents ${ }^{30,31}$. Wheat bran, another agricultural waste was studied for its adsorbent properties ${ }^{32,33}$. In recent years there has been increasing interest in studying also natural waste materials that arise from food industry, e.g. coffee waste ${ }^{34,35}$ those that come through various industrial processes, like coal ash ${ }^{36,37}$ and other natural low cost materials, like bentonitic clays ${ }^{38,39}$.

In present study we've analyzed some low cost materials, olive waste, maize cobs, bentonitic clay, wheat bran, coal ash and coffee waste as potential adsorbents for removing of $\mathrm{Pb}^{2+}, \mathrm{Cu}^{2+}$ and $\mathrm{Zn}^{2+}$ ions from standard solutions.

\section{MATERIALS AND METHODS}

\section{Adsorbent}

The starting materials, maize cobs, wheat bran, and coffee waste were obtained commercially from Kosovo, coal ash was obtained from Thermo Power Plants in Kosovo, bentonitic clay from Vitia, Kosovo while olive waste were obtained from olive oil industry in Ulqin, Montenegro. All the adsorbent used where sieved and dried at $105^{\circ} \mathrm{C}$ to a constant weight.
In terms of physical-chemical properties, chemical composition of ash varies greatly, depending on the type of coal and its origin. Coal ash from our lignite type coal (Thermo power plants Kosova A and B) has specific inorganic composition with predominance of alkaline components ( $\mathrm{CaO}$ and $\mathrm{MgO}$ ), while bentonitic clay although also alumosilikate, has predominance of acidic constituents $\left(\mathrm{SiO}_{2}\right)$. Adsorbents of agricultural origine have high mechanical strength, rigidity and porosity and they have polymeric groups like cellulose, hemi-cellulose, pectin, lignin and proteins as active centers for metal uptake ${ }^{40}$.

\section{General procedure for adsorption studies}

The sorption of $\mathrm{Pb}^{2+}, \mathrm{Cu}^{2+}$ and $\mathrm{Zn}^{2+}$ ions on used adsorbents (olive waste, maize cobs, bentonitic clay, wheat bran, coal ash and coffee waste) was studied using a batch technique. The general method used for this study is described as follows. The stock solution of $\mathrm{PbSO}_{4}, \mathrm{CuSO}_{4}$ and $\mathrm{ZnSO}_{4}$ at a concentration of $10 \mathrm{mg} / \mathrm{L}$ was used in all experimental runs. A known weight of adsorbent (1g and $5 \mathrm{~g}$ ) was equilibrated with $\mathrm{Pb}^{2+}, \mathrm{Cu}^{2+}$ and $\mathrm{Zn}^{2+}$ solutions of known concentrations in a stopped pyrex glass at a fixed temperature in a thermostatic shaker bath (300 rpm) for a known period of time (30 min and $60 \mathrm{~min}$ ). After equilibration, the suspension was filtered and analyzed with AAS.

\section{RESULTS AND DISCUSSION}

Since heavy metals are natural components of the Earth's crust and they cannot be degraded or destroyed, their treatment is of special concern due to their recalcitrance and persistence in the environment. Manufacturing a diversity of adsorbents as raw materials is being studied (olive waste, maize cobs, bentonitic clay, wheat bran, coal ash and coffee waste) since these materials are renewable, usually available in large amounts and less expensive than other materials to. Use of waste materials as inexpensive adsorbents for removing of heavy metal ions from water and wastewater presents a great contribution in the reduction of costs for waste disposal, therefore contributing to environmental protection.

The sorption of $\mathrm{Pb}^{2+}, \mathrm{Cu}^{2+}$ and $\mathrm{Zn}^{2+}$ ions on used adsorbents was studied using a batch 


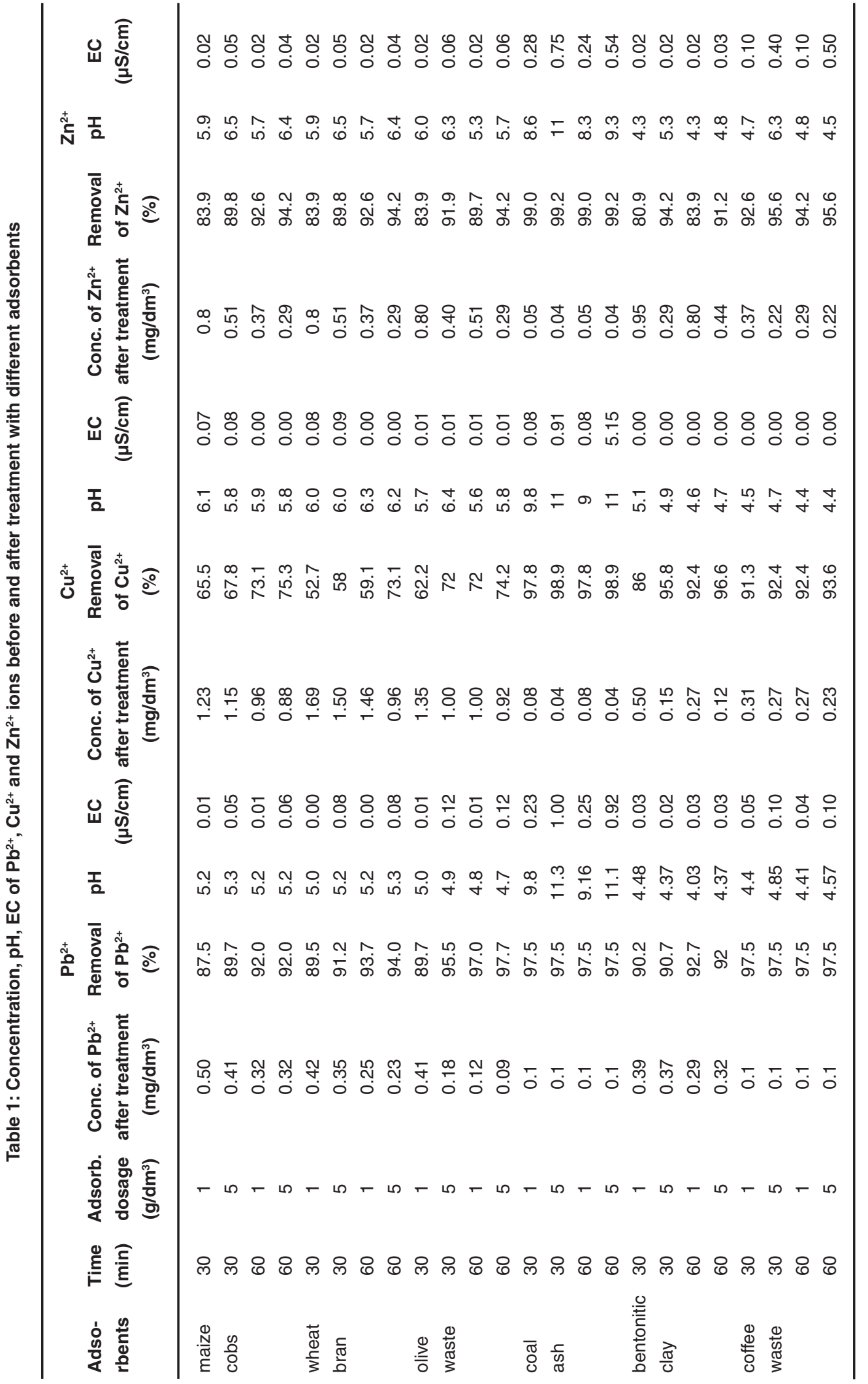


technique. Concentration of heavy metal ions before treatment was $4 \mathrm{mg} / \mathrm{dm}^{3}$ for $\mathrm{Pb}^{2+}$ ions, $3.57 \mathrm{mg} /$ $\mathrm{dm}^{3}$ for $\mathrm{Cu}^{2+}$ ions and for $\mathrm{Zn}^{2+}$ ions it was $4.98 \mathrm{mg} /$ $\mathrm{dm}^{3}$, respectively. $\mathrm{pH}$ of these untreated aqueous solutions were 5.29 for $\mathrm{Pb}^{2+}$ ions, 6.0 for $\mathrm{Cu}^{2+}$ ions and for $\mathrm{Zn}^{2+}$ ions $\mathrm{pH}$ was 5.4, respectively. Electrical conductivity for all heavy metal ions before treatment was $0.00 \mu \mathrm{S} / \mathrm{cm}$. Results of treatment of each heavy metal aqueous solution with used adsorbents are given in Table 1.

From the results shown in Table 1 it can be noted that $\mathrm{pH}$ of aqueous solution of $\mathrm{Pb}^{2+}, \mathrm{Cu}^{2+}$ and $\mathrm{Zn}^{2+}$ ions after treatment with maize cobs, olive waste and wheat bran are almost the same as they were before treatment, while after treatment with coal ash $\mathrm{pH}$ are increased from8.3 to 11.3 due to predominance of alkaline components in our coal ash, while after treatment with bentonitic clay and coffee waste $\mathrm{pH}$ are slightly lower from 4.03 to 6.3, due to their acidic nature. Electrical conductivity of aqueous solution of $\mathrm{Pb}^{2+}, \mathrm{Cu}^{2+}$ and $\mathrm{Zn}^{2+}$ ions after treatment with all used adsorbents was slightly increased from $0.01 \mu \mathrm{S} / \mathrm{cm}$ to $5.15 \mu \mathrm{S} / \mathrm{cm}$ when $5 \mathrm{~g}$ of adsorbents were used.
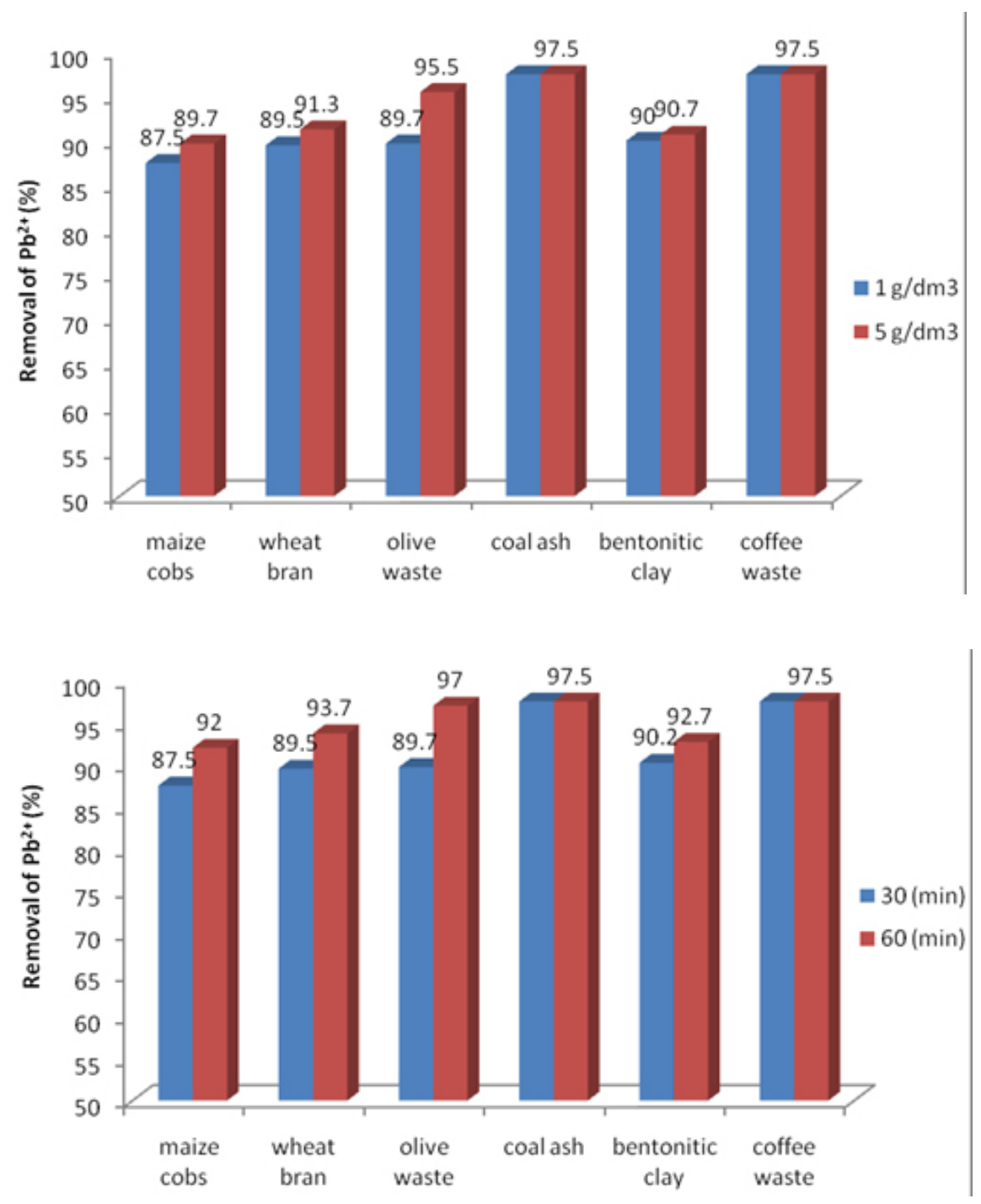

Fig.1: Precentage of removal of lead $\mathrm{Pb}$ (II) in dependence from (a) adsorbent dosage, $1 \mathrm{~g}$ and $5 \mathrm{~g}$; and (b) from time, $30 \mathrm{~min}$ and $60 \mathrm{~min}$ 
Figure $1(a, b)$, Figure $2(a, b)$ and Figure $3(a, b)$ shows data for dependence of percentage removal from adsorbent dosage and contact time respectively.

Adsorbent dosage is an important parameter because this determines the capacity of an adsorbent for a given initial concentration of the adsorbate. The effect of adsorbent (olive waste, maize cobs, bentonitic clay, wheat bran, coal ash and coffee waste) dose on the adsorption of $\mathrm{Pb}^{2+}$ is presented in Figure 1a. As shown in this figure, results of percentage removal of $\mathrm{Pb}^{2+}$ ions are very high with all adsorbent used, ranging from $87.5 \%$ for maize cobs to $97.5 \%$ for coal ash and coffee waste. From this figure it can be noted that there is no significant impact in precentage removal of lead with the increase in adsorbent dosage from $1 \mathrm{~g}$ to $5 \mathrm{~g}$. Slightly greater removal of lead is noticed with olive waste, $6.2 \%$, while with maize cobs $2.2 \%$, wheat bran $1.8 \%$ and bentonitic clay $0.8 \%$ the impact was very small. Coal ash and coffee waste demonstrated no effect when adsorbent dosage was increased.

Figure $1 \mathrm{~b}$ shows the effect of contact time on percentage removal of $\mathrm{Pb}^{2}$. It was observed that
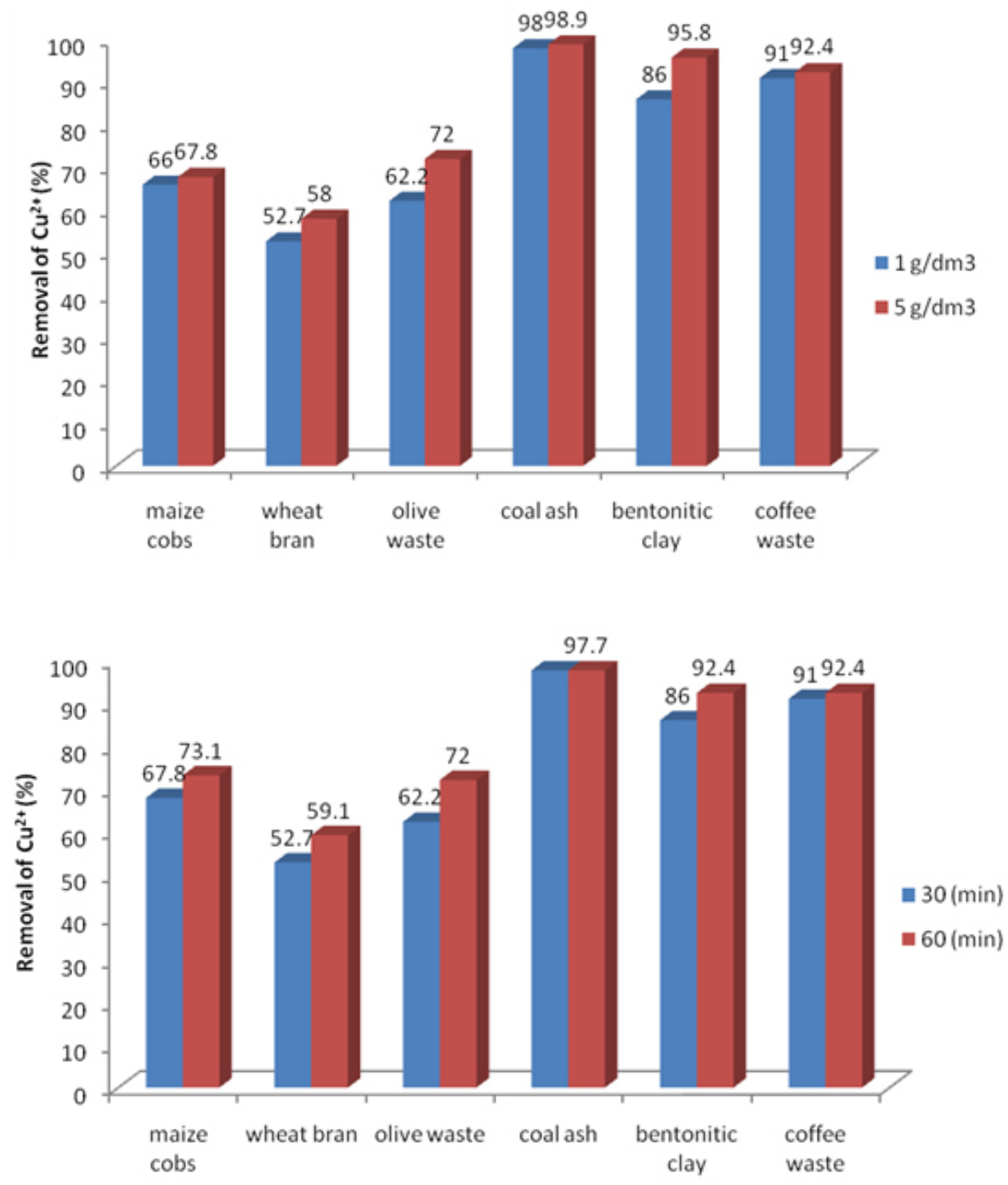

Fig. 2: Precentage of removal of $\mathrm{Cu}$ (II) in dependence from (a) adsorbent dosage, $1 \mathrm{~g}$ and $5 \mathrm{~g}$; and (b) from time, $30 \mathrm{~min}$ and $60 \mathrm{~min}$ 
percentage removal slightly increases with contact time. Highest increase in percentage removal was observed with olive waste, $7.3 \%$ or bentonitic clay showed $2.5 \%$ increase in percentage removal with increase in contact time from $30 \mathrm{~min}$ to $60 \mathrm{~min}$. Coal ash and coffee waste did not show any effect with increase of contact time.

Figure 2(a) shows the effect of adsorbent dose ( 1 and $5 \mathrm{~g} / \mathrm{dm}^{3}$ for $30 \mathrm{~min}$ ) on the adsorption of $\mathrm{Cu}^{2+}$ ions. From these results it can be noted that coal ash was best adsorbent for removal of $\mathrm{Cu}^{2+}$ with $98.9 \%$ of removal while wheat bran removed $52.7 \%$. Increasing adsorbent dose from $1 \mathrm{~g}$ to $5 \mathrm{~g}$ had more effect on removing of $\mathrm{Cu}^{2+}$ ions, e.g., adsorption on olive waste increased for $10.2 \%$ while with wheat bran increasing in percentage removal was $5.3 \%$. Other adsorbents showed small increase for fivefold increase in adsorbent dosage, while coal ash showed no effect in percentage removal of $\mathrm{Cu}^{2+}$ ions.

The effect of contact time on percentage removal of $\mathrm{Cu}^{2}$ is shown in Figure 2(b). It was observed that increasing contact time from $30 \mathrm{~min}$ to $60 \mathrm{~min}$ had more effect on percentage removal of $\mathrm{Cu}^{2+}$ than it did with $\mathrm{Pb}^{2+}$. Highest increase in percentage removal was observed with olive waste,
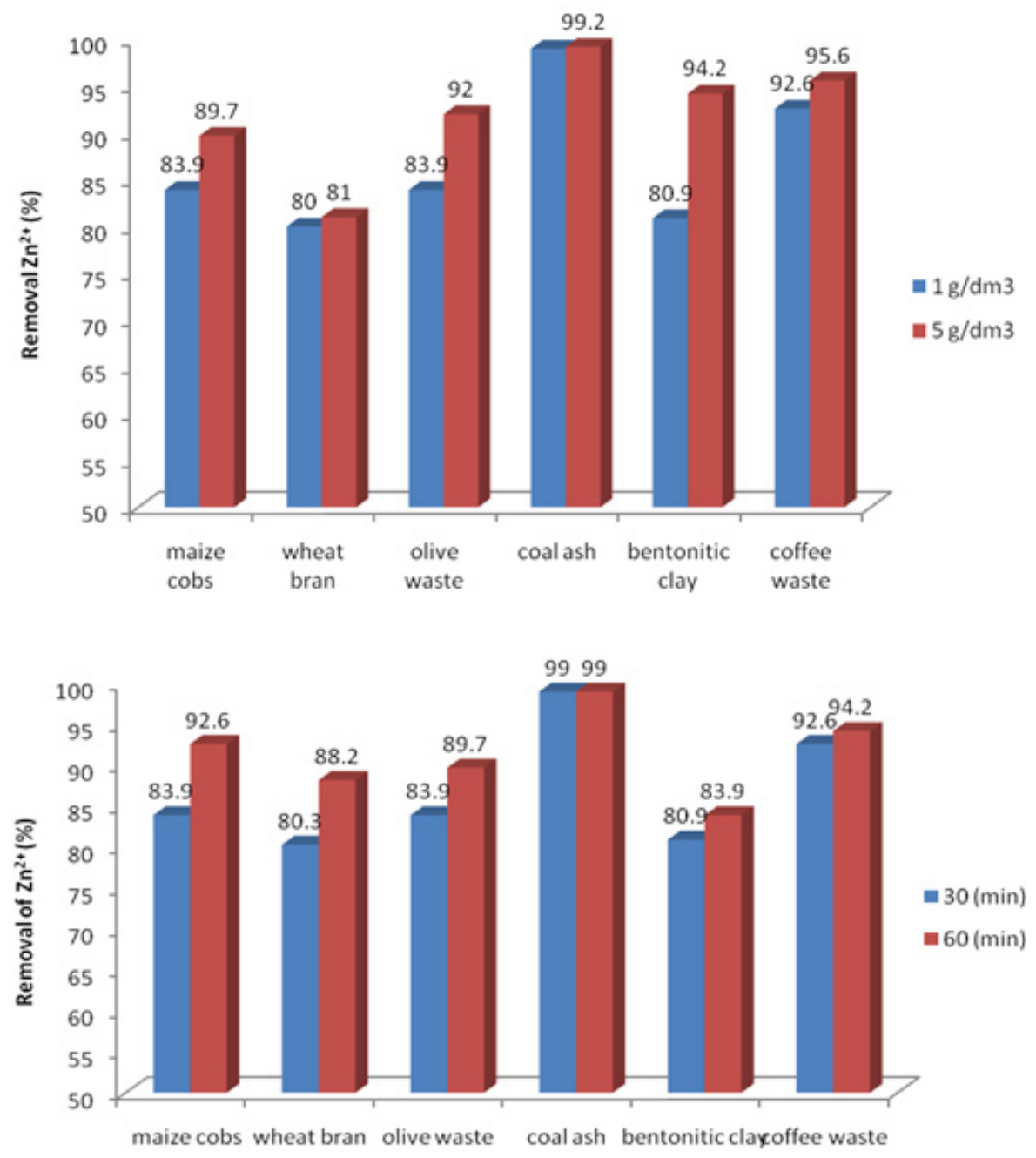

Fig. 3: Precentage of removal of $\mathrm{Zn}$ (II) in dependence from (a) adsorbent dosage, $1 \mathrm{~g}$ and $5 \mathrm{~g}$; and (b) from time, $30 \mathrm{~min}$ and $60 \mathrm{~min}$ 
$10.2 \%$ and wheat bran $7.6 \%$, while bentonitic clay and maize cob showed $6.4 \%$ and $5.3 \%$ respectively. Coal ash did not show any effect with increase of contact time.

Figure 3(a) and 3(b) shows percentage removal of $\mathrm{Zn}^{2+}$ ions from all used adsorbents. Figure 3(a) shows results of percentage removal of $\mathrm{Zn}^{2+}$ after treatment with all adsorbent dosage of $1 \mathrm{~g}$ and $5 \mathrm{~g}$ for 30 min of contact time. It can be noted that adsorbent dosage had most effect in bentonitic clay, increasing percentage of removal for $13.3 \%$ with increasing of dosage for fivefold. Smaller impact was noted with olive waste $8.1 \%$, maize cobs $5.8 \%$, coffee waste $3 \%$, wheat bran $1 \%$, while coal ash showed no impact at all. Both graphs also confirms that most effective adsorbent on removal of $\mathrm{Zn}^{2+}$ was coal ash with over $99 \%$ of total removal and least effective was wheat bran with $80 \%$ of total removal.

Figure 3(b) shows that percentage of removal of $\mathrm{Zn}^{2+}$ ions in dependence of increasing contact time, from $30 \mathrm{~min}$ to $60 \mathrm{~min}$, did not have any effect in coal ash, had a small effect in coffee waste $1.6 \%, 3 \%$ in bentonitic clay, $5.8 \%$ in olive waste, $7.9 \%$ in wheat bran and highest effect was noted for maize cob with $8.7 \%$ increase.

\section{CONCLUSIONS}

The present study shows that all adsorbents used were an effectual biosorbents for removal of
$\mathrm{Pb}^{2+}, \mathrm{Cu}^{2+}$ and $\mathrm{Zn}^{2+}$ ions from aqueous solution. Maize cob was an effective adsorbent with maximal percentage of removal of $92.6 \%$ for $\mathrm{Zn}^{2+}$ and $66 \%$ for $\mathrm{Cu}^{2+}$ ions. Wheat bran was also effective adsorbent for highest removal of $\mathrm{Pb}^{2+}$ with $93.7 \%$ and lowest percentage of removal for $\mathrm{Cu}^{2+}$ with $52.7 \%$. Another adsorbent that showed good sorption properties was olive waste, with highest removal from $97 \%$ for $\mathrm{Pb}^{2+}$ and lowest percentage removal for $\mathrm{Cu}^{2+}$ from $62 \%$. Our preliminary results indicate that coûee waste oûers considerable promise as a low-cost natural adsorbent. Highest efficiency was noticed in removal of $\mathrm{Pb}^{2+}$ with $97.5 \%$ while lowest percentage removal was noticed for $\mathrm{Cu}^{2+}$ with $91 \%$. Bentonitic clay having a structure with net negative charge, which is neutralised by positively charged species, resulted also as an effective low cost adsorbent with max total removal from $92.7 \%$ for $\mathrm{Pb}^{2+}$ to $80.9 \%$ for $\mathrm{Zn}^{2+}$. Most effective adsorbent that we used was coal ash with total removal for all ions over $90 \%$, with highest percentage removal from $99.2 \%$ for $\mathrm{Zn}^{2+}$ ions and $97.5 \%$ of $\mathrm{Pb}^{2+}$. For all adsorbent used adsorbent dosage and contact time did not have significant impact in their adsorption capacities. As conclusion all these agro and industrial waste materials, to overcome environmental pollution, are low cost, eco-friendly and easy alternative instead of using chemicals for the removal of heavy metals and other pollutants.

\section{REFERENCES}

1. Igwe, J.C., Abia, A.A., A bioseparation process for removing heavy metals from waste water using biosorbents. African J. Biotech., 5, 1167-1179, (2006).

2. Kula, I., Ugurlu, M., Karaoglu, H., Celik, A., Adsorption of $\mathrm{Cd}(\mathrm{II})$ ions from aqueous solutions using activated carbon prepared from olive stone by $\mathrm{ZnCl} 2$ activation. Bioresour. Technol. 99, 492-501, (2008).

3. Velmurugan, P., Kumar, R. and Dhinakaran, V. G., Dye removal from aqueous solution using low cost sorbent. Int. J. Environ. Sci., 1, pp. 7-14, (2011).
4. Qdais, H.A., Moussa, H., Removal of heavy metals from wastewater by membrane processes: a comparative study. Desalination 163 (2) 105-110, (2004).

5. Gode, F. and Pehlivan, E. Adsorption of $\mathrm{Cr}$ (III) Ions by Turkish Brown Coals. Fuel Processing Technology, 86, 875-884, (2005).

6. Low, K.S., Lee, C.K., Ng, A.Y., Column study on the sorption of $\mathrm{Cr}(\mathrm{VI})$ using quaternized rice hulls. Bioresour. Technol. 68, 205-208, (1999).

7. Lacour, S., Bollinger, J. C., Serpaud, B., Chantron, P., Arcos, R., Removal of heavy 
metals in industrial wastewaters by ionexchanger grafted textiles. Anal. Chim. Acta., 428 (1), 121-132, (2001).

8. Yu, L.Y., Shukla, S.S., Dorris, K.L., Shukla, A., Margrave, J.L., Adsorption of chromium from aqueous solutions by maple sawdust. J. Hazard Mater. B 100, 53-63, (2003).

9. Gupta, V.K., Ali, I., Advances in water treatment by adsorption technology, Nature protocols, 1, 2661-2667, (2006).

10. Gupta, V.K., Ali, I., Water Treatment for Inorganic Pollutants by Adsorption Technology, Environmental Water, 29-91, (2013).

11. Amit, B., Minocha, A.K., Conventional and nonconventional adsorbents for removal of pollutants. Indian Journal of Chemical Technology, 13, 203-217, (2006).

12. Alinnor, I .J., Adsorption of heavy metal ions from aqueous solution by fly ash, Fuel, 86, pp. 853-857, (2007).

13. Jiuhui, Q.U., Research progress of novel adsorption processes in water purification: a review, Journal of environmental sciences, 20, 1-13, (2008).

14. Volesky, B., Holan, Z.R., Biosorption of heavy metals. Biotechnol Prog 11:235-250, (1995).

15. Sanas, M., Gawande, S.M., Application of flyash-based filter bed in domestic wastewater treatment, International journal of innovative research in technology, 3(1), 83-85, 2016.

16. Tripathi, A., Ranjan, M.R., Heavy Metal Removal from Wastewater Using Low Cost Adsorbents, J Bioremed Biodeg, 6, 315, (2015).

17. Ahsan, S., Kaneco, S., Ohta, K., Mizono, T., Kani, K., Use of some natural and waste materials for waste water treatment. Water Resorces. 35, 3738-3742, (2001).

18. Bestani, B., Benderdouche, N., Benstaali, B., Belhakem, M., Addou, A., Methylene blue and iodine adsorption onto an activated desert plant, Bioresource Technology, 99(17), pp. 8441-8444, (2008).

19. Girods, P., Dufour, A., Fierro, V., Rogaumea, Y., Rogaumea, C., Zoulaliana, A., Celzardc, A., Activated carbons prepared from wood particleboard wastes: Characterisation and phenol adsorption capacities, Journal of Hazardous Materials, 166, 491-501, (2009).

20. Cadena, F., Rizvi, R., Peters, R.W., Feasibility studies for the removal of heavy metals from solution using tailored bentonite. In Hazardous and industrial Wastes, Proceedings of the Twenty - Second Mid-Atlantic Industrial Waste Conference, Drexel University, pp. 77-94, (1990).

21. Sarabjeet, S.A., Dinesh, G., Microbial and plant derived biomass for removal of heavy metals from wastewater. Bioresource Technology, 98, 2243-2257, (2007).

22. Moattar, F., Hayeripour, S., Application of Chitin and Zeolite adsorbents for treatment of low level radioactive liquid wastes. International Journal of Environmental Science \& Technology, 1(1), pp. 45- 50, (2004).

23. Bryant, P.S., Petersen, J.N., Lee, J.M., Brouns, T.M., Sorption of heavy metals by untreated red sawdust, Applied Biochemistry and Biotechnology, 34-35, no. 1, pp. 777-78, (1992).

24. Ajmal, M., Rao, R.A.K., Anwar, S., Ahmad, J., Ahmad, R., Adsorption studies on rice husk: removal and recovery of $\mathrm{Cd}$ (II) from wastewater. Bioresour. Technol., 86, 147-149, (2003).

25. Marshall, W.E., Wartelle, L.H., Boler, D.E., Johns, M.M., Toles, C.A., Enhanced metal adsorption by soybean hulls modified with citric acid. Bioresour. Technol., 69, 263-268, (1999).

26. Ayub, S., Ali, S.I., Khan, N.A., Study on the removal of $\mathrm{Cr}(\mathrm{VI})$ by sugarcane bagasse from wastewater. Pollut. Res. J., 2 (2), 233-237, (2001).

27. Calero de Hoces M., Blázquez García, G., Gálvez, A.R., Martín-Lara, M.A., Effect of the acid treatment of olive stone on the biosorption of lead in a packed-bed column. Ind Eng Chem Res 49:12587-12595, (2010).

28. Aziz, A., Elandaloussi, E.H., Belhalfaoui, B., Ouali, M.S., De Ménorval, L.C., Efficiency of succinylated-olive stone biosorbent on the removal of cadmium ions from aqueous solutions. Colloids Surf B Biointerfaces 73:192-198, (2009). 
29. Babakhouya, N., Aksas, H., Boughrara, S., Louhab, K., Adsorption of Cd(II) Ions from Aqueous Solution using Mixed Sorbents Prepared from Olive Stone and Date Pit. Journal of Applied Sciences, 10: 2316-2321, (2010).

30. Arunkumar, C., Perumal, R., LakshmiNarayanan, S., Arunkumar, J., Use of Corn Cob as Low Cost Adsorbent for the Removal of Nickel (II) From Aqueous Solution. International Journal of Advanced Biotechnology and Research, 5(3), 325-330, (2014).

31. Tsai, W.T., Chang, C.Y., Wang, S.Y., Chang, C.F., Chien, S.F., Sun, H.F., Cleaner production of carbon adsorbents by utilizing agricultural waste corn cob. Res. Conserv. Recycl, 32, 43-53, (2001).

32. Bulut, Y., Baysal, Z., Removal of Pb(II) from wastewater using wheat bran. Journal of Environmental Management 78, 107-113, (2006).

33. Ozer, A., Özer, D. and Özer, A., The adsorption of copper (II) ions onto dehydrated wheat bran (DWB): determination of the equilibrium and thermodynamic parameters, Process Biochemistry, 39, pp. 2183-2191, (2004).

34. Kyzas, G.Z., Commercial Coffee Wastes as
Materials for Adsorption of Heavy Metals from Aqueous Solutions. Materials, 5(10), 1826-1840, (2012).

35. Djati Utomo, H., Hunter, K.A., Adsorption of heavy metals by exhausted coûee grounds as a potential treatment method for waste waters. e-J. Surf. Sci. Nanotech. 4 (2006) 504-506, (2006).

36. Alinnor, I.J., Adsorption of heavy metal ions from aqueous solution by fly ash, Fuel, 86, pp. 853-857, (2007).

37. Kirk, D.W., Charles, Q., Jia, J.Y., Alan, L.T., Wastewater remediation using coal ash, Journal of Material Cycles and Waste Managment, 5, 5-8, (2003).

38. Kubilay, ${ }^{a}$., Gürkan, R., Savran, A., ${ }^{a}$ ahan, T., Removal of $\mathrm{Cu}(\mathrm{II}), \mathrm{Zn}(\mathrm{II})$ and $\mathrm{Co}(\mathrm{II})$ ions from aqueous solutions by adsorption onto natural bentonite. Adsorption, 13; 41-51, (2007).

39. Vega, J.L. Ayala, J., Loredo, J., Iglesias, J.G., Bentonite as adsorbent of heavy metal ions from mine waste leachates, 9th International Mine waste Congress, (2005).

40. Anwar, J., Shafique, U., Waheed-uzZaman, Salman, M., Dar, A., Anwar, S. Removal of $\mathrm{Pb}(\mathrm{II})$ and $\mathrm{Cd}(\mathrm{II})$ from water by adsorption on peels of banana. Bioresour Technol. 101(6):1752-5, (2010). 